\title{
EFISIENSI PRODUKSI USAHATANI KELAPA DALAM (COCOS NUCIFERA LINN) DI KECAMATAN GAUNG ANAK SERKA KABUPATEN INDRAGIRI HILIR
}

\author{
Sisca Vaulina ${ }^{1}$, Khairizal, dan Hajry Arief Wahyudy \\ Fakultas Pertanian Universitas Islam Riau, Pekanbaru \\ e-mail: ${ }^{1)}$ siscavaulina@agr.uir.ac.id
}

\begin{abstract}
Efficiency in a farming process has a very important meaning in efforts to increase income of coconut farmers, especially in planning or developing coconut products that are effective and efficient in producing coconut. The purpose of this research is to analyze technical efficiency, allocative/price and economical of coconut plantation in Gaung Anak Serka Sub-district, Indragiri Hilir Regency. This research uses survey method. The research was conducted in Kecamatan Gaung Anak Serka (GAS), in four villages namely (1) Rambaian village; (2) Idaman village; (3) Iliran Village; (4) Tanjung Harapan village. Total samples were 62 farmers. The study was conducted in May 2017 until December 2017. Data analysis using software Frontier Version 4.1 C. The results showed that the average technical efficiency level achieved was 72.94 percent of maximum productivity. This shows that the farming coconut in Gaung Anak Serka Sub-district has been efficient to technical efficiency, but not yet allocatively/price and economical efficiency. The average value of the overall allocative efficiency is 2.40 and not economically efficient because the economic efficiency value obtained is 1.75 .
\end{abstract}

Keywords: technical efficiency, allocatively efficient/price, economic efficiency, frontier

\section{PENDAHULUAN}

Komoditi perkebunan yang cukup potensial di Propinsi Riau terdiri dari kelapa sawit, kelapa dalam, karet dan sagu. Menurut Abduracham dan Anny (2003), kesesuaian lahan untuk kelapa terdapat di 11 propinsi di Indonesia dan salah satunya di Propinsi Riau.

Provinsi Riau merupakan produsen Kelapa Dalam terbesar di Indonesia. Indragiri Hilir sebagai kabupaten penghasil Kelapa Dalam terbesar di Propinsi Riau dan sudah dikenal dengan hamparan Kelapa Dalam memiliki luas lahan seluas 439.955 ha $(85,11 \%$ dari total luas lahan Propinsi Riau) dengan jumlah produksi 359.372 ton $(85,23 \%$ dari total produksi Propinsi Riau) (BPS, 2015).

Menurut penelitian Damanik (2007) permasalahan Kelapa Dalam di Kabupaten Indragiri Hilir dari segi pengusahaannya dalam bentuk perkebunan rakyat yang bercirikan: (1) hasil usahatani masih bersifat tradisional yaitu berbentuk Kelapa Dalam butiran dan kopra, (2) produktivitas rendah,
(3) modal lemah, (4) teknologi anjuran masih rendah, dan (5) resultante dari faktor-faktor tersebut menyebabkan pendapatan petani berada pada posisi yang tidak mampu mendukung kehidupan dan kesejahteraan secara layak. Pemilikan lahan usahatani yang sempit dan jarak tanam yang tidak teratur serta belum dilaksanakannya penerapan teknologi anjuran didalam pengembangan usahatani, sehingga sangat sukar diharapkan perolehan produksi dan pendapatan yang optimal.

Vaulina dan Saipul (2015), pendapatan petani Kelapa Dalam di Kabupaten Indragiri Hilir tergolong rendah dengan tingkat pendapatan Rp 6.506.317,77/panen atau Rp 2.168.772,59/bulan, dengan asumsi bahwa luas lahan 2,28 Ha; jumlah tanaman menghasilkan 327 pohon; produksi 5395 butir /panen dan harga Rp 1.500/butir. Pangkey, dkk (2016), pendapatan usahatani kelapa di Kecamatan Sinonsayang berkisar antara Rp 3.200.00/bulan - Rp 4.106.000/bulan. Meskipun begitu, Vaulina (2012), keberadaan 
Tabel 1. Luas Lahan, Produksi, Produktivitas dan Jumlah Petani Perkebunan Kelapa Dalam di Kabupaten Indragiri Hilir, Tahun 2014

\begin{tabular}{|c|l|r|r|r|r|}
\hline No & \multicolumn{1}{|c|}{ Kecamatan } & $\begin{array}{r}\text { Luas Lahan } \\
\mathbf{( H a )}\end{array}$ & $\begin{array}{c}\text { Produksi } \\
\mathbf{( K g )}\end{array}$ & $\begin{array}{c}\text { Produktivitas } \\
\text { (Ton/Ha) }\end{array}$ & $\begin{array}{c}\text { Jumlah Petani } \\
\text { (Orang) }\end{array}$ \\
\hline 1 & Keritang & 26.967 & 25.868 .850 & 0,959 & 5.503 \\
\hline 2 & Kemuning & 19 & 16.996 & 0,894 & 24 \\
\hline 3 & Reteh & 24.993 & 17.628 .320 & 0,705 & 5.101 \\
\hline 4 & Sungai Batang & 14.052 & 7.844 .200 & 0,558 & 2.868 \\
\hline 5 & Enok & 44.118 & 30.219 .397 & 0,685 & 9.004 \\
\hline 6 & Tanah Merah & 10.821 & 12.968 .400 & 1,198 & 2.208 \\
\hline 7 & Kuala Indragiri & 25.721 & 14.566 .800 & 0,566 & 5.249 \\
\hline 8 & Concong & 14.166 & 8.607 .600 & 0,608 & 2.891 \\
\hline 9 & Tembilahan & 9.092 & 9.606 .660 & 1,057 & 1.856 \\
\hline 10 & Tembilahan Hulu & 3.645 & 3.739 .200 & 1,026 & 744 \\
\hline 11 & Tempuling & 10.159 & 7.400 .200 & 0,728 & 2.073 \\
\hline 12 & Kempas & 6.100 & 5.323 .200 & 0,872 & 1.245 \\
\hline 13 & Batang Tuaka & 24.391 & 18.746 .910 & 0,768 & 4.978 \\
\hline 14 & Gaung Anak Serka & 15.381 & 7.656 .918 & 0,498 & 3.139 \\
\hline 15 & Mandah & 55.216 & 45.439 .200 & 0,823 & 11.374 \\
\hline 16 & Kateman & 37.689 & 28.802 .400 & 0,764 & 7.692 \\
\hline 17 & Pelangiran & 15.728 & 15.860 .304 & 1,008 & 3.210 \\
\hline 18 & Teluk Belengkong & 3.524 & 6.055 .200 & 1,718 & 719 \\
\hline 19 & Pulau Burung & 10.879 & 9.771 .600 & 0,898 & 2.220 \\
\hline 20 & Gaung & 28.956 & 18.647 .937 & 0,644 & 5.909 \\
\hline & Jumlah & 381.617 & 566.755 .865 & 1,485 & 78.007 \\
\hline
\end{tabular}

Sumber: BPS Kabupaten Indragiri Hilir, 2015 (diolah)

Kelapa Dalam masih merupakan sektor basis dan memberikan multiplier effect yang mempunyai kekuatan untuk mendorong pertumbuhan ekonomi wilayah di Kabupaten Indragiri Hilir. Tarigans (2005), serta perlu adanya diversifikasi usahatani kelapa sebagai upaya untuk meningkatkan pendapatan petani.

Kelapa Dalam adalah salah satu komoditas unggulan di Kabupaten Indragiri Hilir. Hampir diseluruh Kecamatan ditanami Kelapa Dalam. Luas lahan, produksi, produktivitas dan jumlah petani Kelapa Dalam berdasarkan kecamatan dapat dilihat pada Tabel 1.

Berdasarkan Tabel 1, dilihat dari produktivitas Kelapa Dalam, Kecamatan Gaung Anak Serka (GAS) merupakan produktivitas dengan nilai terendah di kabupaten ini yakni 0,498 ton/ha. Tingkat produktivitas Kecamatan GAS jauh lebih rendah daripada tingkat produktivitas rata-rata Kabupaten Indragiri Hilir (1,485 ton/ha), padahal jumlah petani yang ada di Kecamatan GAS cukup banyak berjumlah 3.139 orang. Dengan kata lain telah terjadi inefisiensi produksi Kelapa Dalam di Kecamatan GAS.

Usahatani Kelapa Dalam yang efisien akan mendorong penggunaan faktor-faktor produksi secara optimal, yang selanjutnya akan menentukan pencapaian efisiensi teknis dalam usahatani Kelapa Dalam. Berdasarkan penelitian terdahulu di Kabupaten Indragiri Hilir (Pasaribu, dkk, 2016), dengan menggunakan DEA hanya sebagian kecil petani yang efisien secara teknis, alokatif dan ekonomis.

Produksi yang diperoleh selama proses usahatani akan memperoleh tingkat jual yang selanjutnya merupakan penerimaan petani. Pencapaian efisiensi menjadi syarat keharusan dan kecukupan tercapainya efisiensi ekonomis suatu usahatani dan akan memberikan keuntungan maksimum bagi petani. Efisiensi dalam suatu proses usahatani mempunyai arti sangat penting dalam upaya peningkatan pendapatan petani Kelapa Dalam terutama dalam merencanakan atau 
mengembangkan hasil Kelapa Dalam yang efektif dan efisien dalam memproduksi kelapa. Tujuan penelitian ini untuk menganalisis efisiensi teknis, alokatif/harga dan ekonomis perkebunan Kelapa Dalam di Kecamatan GAS Kabupaten Indragiri Hilir.

\section{KERANGKA TEORITIS}

Soekartawi (2003) menerangkan bahwa dalam terminologi ilmu ekonomi, pengertian efisiensi ini dapat dibedakan menjadi tiga yaitu efisiensi teknis, efisiensi alokatif atau harga dan efisiensi ekonomis. Soekartawi (1993) mengemukakan bahwa efisiensi penggunaan input diartikan sebagai upaya penggunaan input yang sekecil-kecilnya untuk memperoleh output yang sebesar-besarnya. Situasi ini akan terjadi kalau petani mampu membuat suatu upaya Nilai Produk Marginal (NPM) untuk satu kesatuan input sama dengan harga input (Px). Soekartawi (2002), untuk mengetahui penggunaan faktor produksi telah efisien secara teknis, dapat dilakukan dengan menghitung Marginal Physical Product (MPP) masing-masing faktor produksi

Efisiensi merupakan banyaknya hasil produksi fisik yang dapat diperoleh dari kesatuan faktor produksi atau input. Situasi seperti ini akan terjadi apabila petani mampu membuat suatu upaya agar nilai produk marginal (NPM) untuk suatu input atau masukan sama dengan harga input $(\mathrm{P})$ atau dapat dituliskan sebagai berikut (Soekartawi, 2003):

NPMx $=P x ;$ atau NPMx $/ \mathrm{Px}=1$

Dalam banyak kenyataan NPMx tidak selalu sama dengan $\mathrm{Px}$, dan yang sering terjadi adalah keadaan sebagai berikut:

1. (NPMx / Px) > 1 ; artinya bahwa penggunaan input $x$ belum efisien. Untuk mencapai tingkat efisiensi maka input harus ditambah.

2. $(\mathrm{NPMx} / \mathrm{Px})<1$; artinya penggunaan input $x$ tidak efisien. Untuk mencapai atau menjadi efisien maka input harus dikurangi.

\section{EFISIENSI TEKNIS}

Efisiensi teknis ini mencakup mengenai hubungan antara input dan output. Suatu perusahaan dikatakan efisien secara teknis bilamana produksi dengan output terbesar yang menggunakan set kombinasi beberapa input tertentu. Menurut Miller dan Meiners (2000) efisiensi teknis (technical efficiency) mengharuskan atau mensyaratkan adanya proses produksi yang dapat memanfaatkan input yang lebih sedikit demi menghasilkan output dalam jumlah yang sama.

Dalam usahatani Kelapa Dalam, efisiensi teknis dipengaruhi oleh kuantitas penggunaan faktor-faktor produksi. Kombinasi dari lahan, jumlah tanaman menghasilkan, terusi, garam, pestisida dan tenaga kerja dapat mempengaruhi tingkat efisiensi teknis. Proporsi penggunaan masing-masing faktor produksi tersebut berbeda-beda pada setiap petani, sehingga masing-masing petani memiliki tingkat efisiesi yang berbeda-beda. Seorang petani dapat dikatakan lebih efisien dari petani lain jika petani tersebut mampu mengunakan faktor-faktor produksi lebih sedikit atau sama dengan petani lain, namun dapat menghasilkan tingkat produksi yang sama atau bahkan lebih tinggi dari petani lainnya.

\section{EFISIENSI HARGA ATAU ALOKASI}

Efisiensi harga atau alokatif menujukkan hubungan biaya dan output. Efisiensi alokatif tercapai jika perusahaan tersebut mampu memaksimalkan keuntungan yaitu menyamakan nilai produk marginal setiap faktor produksi dengan harganya. Bila petani mendapatkan keuntungan yang besar dari usahataninya, misalnya karena pengaruh harga, maka petani tersebut dapat dikatakan mengalokasikan input usahataninya secara efisien. Efisiensi alokatif ini terjadi bila perusahaan memproduksi output yang paling disukai oleh konsumen (Mc. Eachern, 2001). 


\section{EFISIENSI EKONOMIS}

Efisiensi ekonomis terjadi apabila efisiensi teknik dan efisiensi alokatif tercapai dan memenuhi dua kondisi, yaitu:

a. Syarat keperluan (necessary condition) menunjukkan hubungan fisik antara input dan output, bahwa proses produksi pada waktu elastisitas produksi antara 0 dan 1. Hasil ini merupakan efisiensi produksi secara teknik.

b. Syarat kecukupan (sufficient cindition) yang berhubungan dengan tujuannya yaitu kondisi keuntungan maksimum tercapai dengan syarat nilai produk marginal sama dengan biaya marginal.

Konsep yang digunakan dalam efisiensi ekonomis adalah meminimalkan biaya artinya suatu proses produksi akan efisien secara ekonomis pada suatu tingkatan output apabila tidak ada proses lain yang dapat menghasilkan output serupa dengan biaya yang lebih murah. Dalam usahatani kelapa, efisiensi ekonomis dipengaruhi oleh harga jual kelapa (Kg) dan total biaya produksi (TC) yang digunakan. Harga jual kelapa akan mempengaruhi total penerimaan (TR). Usahatani kelapa dapat dikatakan semakin efisien secara ekonomis jika usahatani tersebut semakin menguntungkan.

Menurut Nicholson (2002), alokasi sumber daya disebut efisien secara teknis jika alokasi tersebut tidak mungkin meningkatkan output suatu produk tanpa menurunkan produksi jenis barang lain. Lebih lanjut dijelaskan oleh Farrel dalam Adiyoga (1999) bahwa jika diasumsikan usahatani menggunakan dua jenis input $X_{1}$ dan $X_{2}$ untuk memproduksi output tunggal $y$ seperti terlihat pada Gambar 1. Dengan asumsi constant return to scale maka fungsi frontier dapat dicirikan oleh suatu unit isokuan yang efisien.

Gambar 1 menunjukkan bahwa harga faktor produksi relative diperlukan untuk mengetahui efisiensi harga. Garis harga faktor produksi $\mathrm{X}_{1}$ dan $\mathrm{X}_{2}$ ditunjukkan oleh garis $\mathrm{PP}^{\prime}$ menyinggung kurva $\mathrm{UU}^{\prime}$ pada $\mathrm{D}$ dan memotong garis OC pada titik A. Garis $\mathrm{PP}^{\prime}$ adalah garis yang menunjukkan tempat kedudukan kombinasi penggunaan input untuk memperoleh satu unit output dengan biaya yang paling rendah ditunjukkan titik singgung D pada kurva UU'.

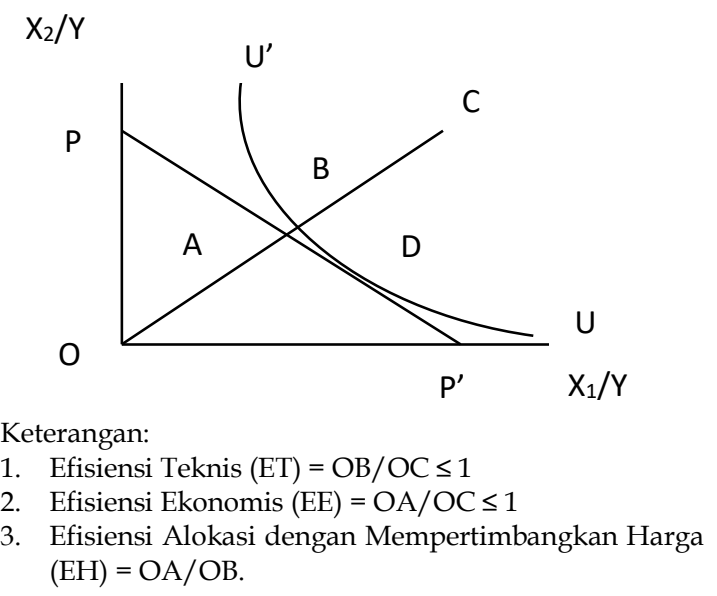

\section{Gambar 1. Efisiensi Unit Isoquan} Sumber: Soekartawi (2003)

Oleh karena itu, efisiensi harga bergerak pada titik OA/OB. Efisiensi ekonomis sebagai hasil dari efisiensi teknis dan harga OB/OC $x$ $\mathrm{OA} / \mathrm{OB}=\mathrm{OA} / \mathrm{OC}$. Dalam teori ekonomi, asumsi dasar sifat fungsi produksi adalah hukum kenaikan hasil yang semakin menurun (The law of diminishing return). Spesifikasi bentuk fungsi produksi tersebut dijabarkan dalam tiga tahap yaitu:

1. Tahap pertama (I) di mana elastisitas produksi EP > 1, merupakan daerah irrasional karena produsen masih dapat meningkatkan outputnya melalui peningkatan input.

2. Tahap kedua (II) di mana $0 \leq \mathrm{EP} \leq 1$ merupakan daerah rasional untuk membuat keputusan produksi dan daerah ini terjadi apa yang disebut dengan efisiensi.

3. Tahap tiga (III) dengan EP $<0$ disebut daerah irrasional karena penambahan input akan mengurangi output. 


\section{FUNGSI PRODUKSI FRONTIER STOKHASTIK}

Fungsi produksi frontier adalah suatu fungsi produksi yang dipakai untuk mengukur bagaimana fungsi produksi sebenarnya terhadap posisi frontiernya. Karena fungsi produksi adalah hubungan fisik antara faktor produksi dan produksi ada frontiernya yang terletak pada garis isokuan. Garis isokuan ini adalah tempat kedudukan titik-titik yang menunjukkan titik kombinasi penggunaan produksi yang optimal (Soekartawi, 2005).

Dalam teori mikroekonomi, teknologi produksi dinyatakan sebagai fungsi transformasi atau produksi yang mendefinisikan pencapaian output maksimal dari berbagai kombinasi input. Dengan demikian, fungsi transformasi menggambarkan suatu batas atau frontier produksi (Adiyoga, 1999).

Karakteristik penting dari model produksi frontier adalah adanya pemisahan dampak dari shok variabel exogenous terhadap output dengan kontibusi variabel dalam bentuk efisiensi teknik. Aplikasi ini dimungkinkan untuk mengestimasi ketidakefisienan suatu produksi tanpa mengabaikan kesalahan baku dari modelnya. Hal ini dimungkinkan karena kesalahan baku (term error) dalam model (e), terdiri dari dua kesalahan baku yang keduanya terdistribusi secara bebas (normal) dan sama untuk setiap observasi. Pertama adalah kesalahan baku yang ada dalam suatu model (v) dan yang kedua adalah ketidakefisienan $(\mathrm{u})$ dan $\mathrm{e}=\mathrm{v}-$ u (Sukiyono, 2004). Secara matematis dapat ditulis sebagai berikut:

$Y=f(x) \exp (v-u)$

Dimana $\mathrm{f}(\mathrm{x}) \exp (\mathrm{v})$ adalah stochastic frontier production. Menurut Forsund, dkk (1980), v harus menyebar mengikuti sebaran atau distribusi yang simetrik sehingga dapat "menangkap" kesalahan (error) dan variabel lain yang ikut mempengaruhi nilai-nilai $X$ dan Y. Sedangkan nilai exp (u) menunjukkan nilai inefisiensi teknis (technical in-efficiency).

\section{METODE PENELITIAN}

Penelitian ini menggunakan metode survey. Penelitian dilaksanakan di Kecamatan Gaung Anak Serka (GAS), pada empat desa yakni (1) Desa Rambaian; (2) Desa Idaman; (3) Desa Iliran; (4) Desa Tanjung Harapan. Lokasi penelitian ditentukan secara purposive dengan pertimbangan bahwa desa tersebut terdapat petani Kelapa Dalam yang memiliki produktivitas rendah. Total keseluruhan sampel sebanyak 62 orang petani Kelapa Dalam. Penelitian dilaksanakan pada bulan mei 2017 sampai dengan desember 2017.

\section{ANALISIS DATA}

a) Efisiensi Teknis

Efisiensi teknis adalah upaya penggunaan input yang sekecil-kecilnya untuk mendapatkan produksi yang sebesarbesarnya (Soekartawi, 2002). Dalam penelitian ini nilai efisiensi teknisnya secara otomatis terlihat dari hasil output software Frontier Version 4.1C.

b) Efisiensi Harga

Efisiensi harga akan terjadi jika nilai produk marjinal sama dengan harga input tersebut sehingga dapat dituliskan sebagai berikut (Soekartawi, 2003).

$$
\begin{aligned}
& \text { NPMx }=\text { Px atau, } \frac{\text { NPMx }}{P x}=1 \ldots \ldots \\
& \frac{\text { b. Y.Py }}{X}=P x \text { atau, } \frac{\text { b. Y.Py }}{X . P x}=1 \ldots
\end{aligned}
$$

$$
\begin{aligned}
& \text { Keterangan: } \\
& \mathrm{b}=\text { Elastisitas } \\
& \mathrm{Y}=\text { Produksi } \\
& \mathrm{Py}=\text { Harga produksi } \mathrm{Y} \\
& \mathrm{X}=\text { Jumlah faktor produksi } \mathrm{X} \\
& \mathrm{PX}=\text { Harga faktor produksi } \mathrm{X}
\end{aligned}
$$

Kriteria:

1. Jika $\frac{\mathrm{NPM}_{\mathrm{x}}}{\mathrm{P}_{\mathrm{x}}}>1$ maka penggunaan input $x$ belum efisien. Untuk mencapai efisien, input $x$ harus ditambah. 
2. Jika $\frac{\mathrm{NPM}_{\mathrm{x}}}{\mathrm{P}_{\mathrm{x}}}<1$ maka penggunaan input $\mathrm{x}$ tidak efisien. Untuk mencapai efisien input $x$ perlu dikurangi.

c) Efisiensi Ekonomi

Menurut Soekartawi (2003), efisiensi ekonomi merupakan hasil kali antara seluruh efisiensi harga/alokatif dari seluruh faktor input. Efisiensi ekonomi usahatani padi dapat dinyatakan sebagai berikut:

$\mathrm{EE}=\mathrm{TER} . \mathrm{AER}$

Keterangan:

$\mathrm{EE}=$ Efisiensi ekonomi

TER = Tehnical Efficiency Rate

$\mathrm{AER}=$ Allocative Efficiency Rate

\section{HASIL DAN PEMBAHASAN}

Menurut Seiford et al., dalam Coelli et al. (2005), fungsi produksi frontier adalah suatu fungsi yang menunjukan kemungkinan tertinggi yang mungkin dicapai oleh petani dengan kondisi yang ada dilapangan, dimana produksi secara teknis telah efisien dan tidak ada cara lain untuk memperoleh output yang lebih tinggi lagi tanpa menggunakan input yang lebih banyak dari yang dikuasai oleh petani. Dengan perkataan lain tingkat produksi yang ditonjolkan oleh fungsi produksi frontier ini menunjukan tingkat produksi potensial yang mungkin dicapai oleh petani dengan pengelolaan yang lebih baik.
Hubungan antara faktor-faktor produksi dan tingkat produksi Kelapa Dalam serta hasil estimasi dari fungsi produksi frontier tersebut dapat dilihat pada Tabel 2.

\section{FAKTOR PRODUKSI KELAPA DALAM}

Berdasarkan analisis yang dilakukan dan fungsi produksi frontier yang terbentuk, diketahui bahwa besaran nilai koefisien regresi pada usahatani Kelapa Dalam di kecamatan Gaung Anak Serka untuk Lahan sebesar 0,6172, Tenaga kerja 0,1948, Tanaman menghasilkan 0,4225, Trusi 0,0656, Garam 0,1053 dan Pestisida 0,0636.

\section{Luas Lahan $\left(\beta_{1}\right)$}

Variabel luas lahan tidak berpengaruh signifikan terhadap produksi kelapa. Jumlah penggunaan luas lahan pada usahatani Kelapa Dalam di kecamatan Gaung Anak Serka memiliki nilai koefisien regresi sebesar 0,6172, ini berarti bahwa setiap peningkatan penggunaan jumlah luas lahan sebesar 1 persen, akan meningkatkan total produksi sebesar 0,6172 persen. Kepemilikan lahan petani rata-rata seluas 2,19 hektar. Sama halnya pada penelitian Vaulina dan Saipul (2015), bahwa luas lahan tidak berpengaruh terhadap produksi kelapa. Dilihat dari luas lahan, petani memiliki lahan yang luas, namun jumlah populasi tanaman berbeda dan jarak tanam pun berbeda.

Upaya yang dapat dilakukan untuk peningkatan produksi yang maksimum yaitu dengan penambahan input dari sisi fisik

Tabel 2. Analisis Fungsi Produksi Frontier Pada Usahatani Kelapa Dalam dengan Metode MLE per Luas Garapan di Kecamatan Gaung Anak Serka Tahun 2017

\begin{tabular}{|c|l|r|r|c|}
\hline No & \multicolumn{1}{|c|}{ Variabel } & Koefisien & t-hitung & \multicolumn{1}{c|}{ Keterangan } \\
\hline 1. & Konstanta $\left(\beta_{0}\right)$ & 4,3421 & 7,6607 & Tidak Signifikan \\
\hline 2. & Luas Lahan $\left(\beta_{1}\right)$ & 0,6172 & 3,6604 & Tidak Signifikan \\
\hline 3. & Tenaga Kerja $\left(\beta_{2}\right)$ & 0,1948 & 1,4505 & Tidak Signifikan \\
\hline 4. & Jumlah Tanaman Menghasilkan $\left(\beta_{3}\right)$ & 0,4225 & 3,3630 & Tidak Signifikan \\
\hline 5. & Terusi $\left(\beta_{4}\right)$ & 0,0656 & 0,5095 & Signifikan \\
\hline 6. & Garam $\left(\beta_{5}\right)$ & 0,1053 & 1,6792 & Tidak Signifikan \\
\hline 7. & Pestisida $\left(\beta_{6}\right)$ & 0,0636 & 0,3780 & Signifikan \\
\hline & Mean TE & & & 0,7294 \\
\hline
\end{tabular}


untuk lahan. Penambahan luas lahan usahatani Kelapa Dalam dari luas $21.900 \mathrm{~m}^{2}$ mencapai $35.417 \mathrm{~m}^{2}$. Dengan demikian produksi dapat diperoleh secara maksimum.

\section{Tenaga Kerja $\left(\beta_{2}\right)$}

Jumlah penggunaan tenaga kerja pada petani Kelapa Dalam memiliki nilai koefisien regresi sebesar 0,1948 ini berarti bahwa setiap peningkatan penggunaan tenaga kerja sebesar 1 persen, akan meningkatkan total produksi sebesar 0,1948 persen. Variabel tenaga kerja tidak berpengaruh signifikan terhadap produksi kelapa. Tenaga kerja yang digunakan umumnya tenaga kerja dalam keluarga. Berdasarkan analisis jumlah tenaga kerja yang paling banyak dibutuhkan pada tahapan pengendalian gulma yaitu sebesar 6,48 HKP atau $(33,82 \%)$ dari total penggunaan tenaga kerja. Berbeda halnya dengan penelitian Lamusa (2005), tenaga kerja berpengaruh terhadap produksi kelapa di Kabupaten Donggala.

\section{Jumlah Tanaman Menghasilkan $\left(\beta_{3}\right)$}

Jumlah tanaman menghasilkan tidak berpengaruh signifikan terhadap produksi kelapa. Masih banyak terdapat tanaman yang sudah tua dan rusak, sehingga dapat mengurangi jumlah buah pada tandan kelapa. Pada usahatani Kelapa Dalam jumlah input benih memiliki nilai koefisien regresi sebesar 0,4225 ini berarti bahwa setiap peningkatan jumlah tanaman menghasilkan sebesar 1 persen, akan meningkatkan total produksi sebesar 0,4225 persen. Oleh sebab itu agar penggunaan jumlah tanaman menghasilkan berada pada tingkat $\mathrm{MPP}=0$ maka penggunaan jumlah tanaman menghasilkan harus ditambah dari penggunaan semula yaitu 232 batang per luas garapan atau (106 btg/hektar) menjadi sebanyak 163 batang per luas garapan atau (75 btg/hektar).

\section{Terusi $\left(\beta_{4}\right)$}

Terusi berpengaruh signifikan terhadap produksi kelapa dalam. Pada umumnya petani sampel apabila tanaman kelapa sudah mulai menurun produksinya, petani biasanya memberikan terusi agar produksi bisa tetap bahkan bertambah. Senada dengan penelitian Lamusa (2005), bahwa pupuk berpengaruh terhadap produksi kelapa.

Pada usahatani Kelapa Dalam jumlah input trusi memiliki nilai koefisien regresi sebesar 0,0656 ini berarti bahwa setiap peningkatan jumlah pupuk terusi sebesar 1 persen, akan meningkatkan total produksi sebesar 0,0656 persen.

\section{Garam $\left(\beta_{5}\right)$}

Garam tidak berpengaruh signifikan terhadap produksi kelapa. Nilai koefisien regresi pada penggunaan garam pada usahatani Kelapa Dalam sebesar 0,1053 artinya adalah setiap peningkatan 1 persen penggunaan garam akan diikuti dengan peningkatan total produksi sebasar 0,1053 persen.

\section{Pestisida $\left(\beta_{6}\right)$}

Pestisida berpengaruh secara signifikan terhadap produksi kelapa. Apabila disekitar pohon kelapa bersih dari gulma, maka akan berpengaruh terhadap buah kelapa. Nilai koefisien regresi pada pestisida bernilai 0,0636 ini berarti bahwa setiap peningkatan penggunaan pestisida sebesar 1 persen, dapat meningkatkan total produksi sebesar 0,0636 persen. Agar peningkatan produksi yang maksimal maka penggunaan pestisida sebelumnya berjumlah 6,77 liter per garapan (3,09 $\mathrm{ltr} / \mathrm{ha})$ ditingkatkan menjadi 7,20 liter per garapan $(3,28 \mathrm{ltr} / \mathrm{ha})$.

\section{EFISIENSI TEKNIS}

Efisiensi teknis merupakan ukuran dari kemampuan produksi yang terbaik serta keluaran optimal yang mungkin dapat dicapai dari beberapa masukan dan teknologi yang digunakan (Coelli et al., 2005).

Efisiensi teknis dapat diukur dengan menggunakan fungsi produksi frontier. Fungsi produksi frontier adalah suatu fungsi yang menunjukan kemungkinan produksi 
Tabel 3. Distribusi Frekuensi Efisiensi Teknis Fungsi Produksi Frontier Pada Usahatani Kelapa Dalam per Luas Garapan di kecamatan Gaung Anak Serka Tahun 2017

\begin{tabular}{|l|c|c|c|}
\hline No & Efisiensi Teknis (\%) & $\begin{array}{c}\text { Jumlah Petani } \\
\text { (Orang) }\end{array}$ & Persentase (\%) \\
\hline 1. & $0,39-0,46$ & 2 & 3,23 \\
\hline 2. & $0,47-0,54$ & 1 & 1,61 \\
\hline 3. & $0,55-0,62$ & 3 & 4,84 \\
\hline 4. & $0,63-0,70$ & 14 & 22,58 \\
\hline 5. & $0,71-0,78$ & 21 & 33,87 \\
\hline 6. & $0,79-0,86$ & 18 & 29,03 \\
\hline 7. & $0,87-0,93$ & 3 & 4,84 \\
\hline Jumlah & & 62 & $\mathbf{1 0 0}$ \\
\hline ET Maksimum & & & 0,8994 \\
\hline ET Minimum & & & 0,3865 \\
\hline ET Rerata & & & 0,7294 \\
\hline N & & & 62 \\
\hline
\end{tabular}

tertinggi yang dapat dicapai oleh petani dengan kondisi yang ada dilapangan, dimana produksi secara teknis telah efisien. Rekha (2016), produksi kelapa di Karnataka sangat efisien secara teknis, efisiensi teknis produksi kelapa bervariasi dari $67 \%$ - 99\% dengan ratarata $89 \%$. Hal ini berbeda dengan hasil penelitian Aumora, dkk (2016) bahwa usahatani kelapa di Kecamatan Pulau Burung Kabupaten Indragiri Hilir tidak efisien sebanyak 64\% (29 orang). Berikutnya Margono dan Sharma (2004), rata-rata efisiensi teknis sekitar 50\% ini menunjukkan bahwa tingkat pendidikan dan perbedaan sektoral berpengaruh terhadap efisiensi teknis.

Berikut hasil estimasi efisiensi teknis fungsi produksi frontier untuk usahatani Kelapa Dalam di kecamatan Gaung Anak Serka pada Tabel 3.

Berdasarkan Tabel 3, Rata-rata tingkat efisiensi teknis yang dicapai oleh petani Kelapa Dalam adalah sebesar 0,7294 dari 62 orang responden, artinya bahwa secara keseluruhan rata-rata produksi yang dicapai pada usahatani Kelapa Dalam didaerah penelitian adalah sebesar 72,94 persen.

Perbedaan tingkat efisiensi yang dicapai petani mengindikasikan tingkat penguasaan dan aplikasi teknologi yang berbeda-beda. Perbedaan tingkat penguasaan teknologi dapat disebabkan oleh atribut yang melekat pada diri petani seperti umur, pendidikan, pengalaman berusahatani, tanggungan ke- luarga juga dapat disebabkan oleh faktor lain seperti penyuluhan. Perbedaan dalam aplikasi teknologi yaitu dalam hal penggunaan input produksi disamping disebabkan oleh tingkat penguasaan teknologi, juga disebabkan oleh kemampuan petani untuk mendapatkan input produksi.

\section{ANALISIS EFISIENSI ALOKATIF/HARGA}

Tingkat efisiensi harga ditunjukkan oleh besarnya Nilai Produk Marginal (NPM). Efisien dapat diartikan sebagai upaya penggunaan input sekecil-kecilnya untuk memperoleh output yang maksimal atau dengan kata lain NPM suatu input $X$ tersebut sama dengan harga input $X$ itu sendiri $(\mathrm{NPM}=1)$, Tetapi dalam kenyataan NPMx atau efisiensi harga/alokatif tidak selalu sama dengan satu, yang sering terjadi adalah lebih besar dari 1 atau lebih kecil dari 1. Apabila lebih besar dari 1 dapat diartikan bahwa penggunaan faktor produksi $X$ belum efisien, sedangkan apabila lebih kecil dari 1 maka dapat diartikan bahwa penggunaan faktor produksi X sudah tidak efisien (Soekartawi, 1995). Anyanwu et al. (2014), efisiensi alokatif menunjukkan kemampuan suatu perusahaan (dalam hal ini petani) untuk menggunakan input dalam proporsi yang optimal pada masing-masing harga. 
Tabel 4. Distribusi Nilai Efisiensi Alokatif/Harga Usahatani Kelapa Dalam

\begin{tabular}{|c|c|c|c|c|c|c|c|}
\hline No & \multicolumn{3}{|r|}{ Variabel } & $\begin{array}{c}\text { Input } \\
(\mathrm{Xi})\end{array}$ & $\begin{array}{l}\text { Harga Input } \\
\text { (Pxi) }\end{array}$ & $\begin{array}{c}\text { Koefisien } \\
(\beta)\end{array}$ & $\mathrm{NPM}_{\mathbf{x}}$ \\
\hline 1. & \multicolumn{3}{|c|}{ Lahan $\left(\beta_{1}\right)$} & 2.19 & $550.000,00$ & 0,6172 & 0,04 \\
\hline 2. & \multicolumn{3}{|c|}{ Tenaga Kerja $\left(\beta_{2}\right)$} & 19,16 & $75.000,00$ & 0,1948 & 1,17 \\
\hline 3. & \multicolumn{3}{|c|}{ Jumlah Tan Menghasilkan $\left(\beta_{3}\right)$} & 162,31 & $6.972,97$ & 0,4225 & 3,21 \\
\hline 4. & \multicolumn{3}{|c|}{ Terusi $\left(\beta_{4}\right)$} & 4,48 & $39.051,72$ & 0,0656 & 3,23 \\
\hline 5. & \multicolumn{3}{|c|}{$\operatorname{Garam}\left(\beta_{5}\right)$} & 88,55 & $2.077,59$ & 0,1053 & 4,93 \\
\hline 6. & \multicolumn{3}{|c|}{ Pestisida $\left(\beta_{6}\right)$} & 6,77 & $44.396,55$ & 0,0636 & 1,82 \\
\hline \multicolumn{4}{|c|}{ Produksi (Y) } & & & & $2.847,26$ \\
\hline \multicolumn{4}{|c|}{ Harga Produksi (Py) } & & & & $3.023,39$ \\
\hline \multicolumn{4}{|c|}{ Efisiensi Teknis (ET) } & & & & 0,7294 \\
\hline \multicolumn{4}{|c|}{ Efisiensi Alokatif/Harga (EA) } & & & & 2,40 \\
\hline \multicolumn{4}{|c|}{ Efisiensi Ekonomi (EE=ETxEA) } & & & & 1,75 \\
\hline \multicolumn{2}{|c|}{ Keterangan: } & $\begin{array}{l}\text { NPM } \\
\beta \\
\text { Y } \\
\text { Py } \\
\text { Xi } \\
\text { Pxi }\end{array}$ & $\begin{array}{l}=\text { Nilai Produk Ma } \\
=\text { Koefisien Regres } \\
=\text { Produksi Rata-ra } \\
=\text { Harga Produksi } \\
=\text { Input Rata-rata } \\
=\text { Harga Input Rata }\end{array}$ & Y.Py/Xi.Px & $=1)$ & & \\
\hline
\end{tabular}

Hasil analisis alokasi efisiensi harga dimana variabel yang dianalisis adalah: lahan $\left(\beta_{1}\right)$, tenaga kerja $\left(\beta_{2}\right)$, jumlah tanaman menghasilkan $\left(\beta_{3}\right)$, terusi $\left(\beta_{4}\right)$, garam $\left(\beta_{5}\right)$ dan pestisida $\left(\beta_{6}\right)$. Untuk lebih jelas efisiensi alokatif pada usahatani Kelapa Dalam di kecamatan Gaung Anak Serka dapat dilihat pada Tabel 4 .

Dilihat dari Tabel 4 menunjukkan bahwa rasio antara Nilai Produk Marginal (NPM) dari faktor produksi lahan dengan harga Lahan yang berlaku saat penelitian adalah 0,04 (NPM < 1). Hal itu menunjukkan bahwa secara ekonomis alokasi dari faktor produksi lahan pada tingkat $21.900 \mathrm{M}^{2}$ sudah tidak efisien. Oleh sebab itu penggunaan biaya input lahan harus dikurangi hingga berada pada tingkat optimum.

Berikut rasio antara Nilai Produk Marginal (NPM) dari faktor produksi Tenaga Kerja dengan harganya dalam satu periode musim tanam adalah 1.17 (NPM>1). Hal itu menunjukkan bahwa secara ekonomis alokasi dari faktor produksi tenaga kerja dengan penggunaan pada tingkat 19,16 HKP belum efisien. Oleh sebab itu penggunaan input tenaga kerja harus tambah hingga berada pada tingkat optimum.

Rasio antara NPM dari faktor produksi Jumlah Tanaman Menghasilkan dengan nilai harga beli per batangnya adalah lebih besar dari 1 yaitu sebesar 3,21 (NPM >1). Hal itu berarti bahwa secara ekonomis alokasi dari faktor produksi jumlah tanaman menghasilkan pada tingkat 163 batang per garapan belum efisien. Maka pengalokasian jumlah tanaman setiap garapan harus ditambah agar diperoleh penggunaan input jumlah tanaman menghasilkan yang optimum.

Rasio antara NPM dari faktor produksi pupuk Terusi dengan harga beli per kilogram adalah lebih besar dari 1 yaitu sebesar 3,23 (NPM > 1). Hal itu berarti bahwa secara ekonomis alokasi dari faktor produksi pupuk terusi pada tingkat 4,48 kilogram per luas garapan belum efisien.

Demikian pula halnya dengan Rasio antara NPM dengan faktor produksi Garam dengan nilai yang lebih besar dari 1 yaitu sebesar 4,93 (NPM >1). Hal itu berarti bahwa secara ekonomis faktor produksi garam pada tingkat penggunaan 88,55 kilogram belum efisien. Oleh sebab itu untuk meningkatkan hasil produksi usahatani Kelapa Dalam di kecamatan Gaung Anak Serka dapat dilakukan dengan cara menambah pengalokasian faktor produksi garam hingga penggunaan input tersebut berada pada tingkat optimum.

Rasio antara Nilai Produk Marginal (NPM) dari faktor produksi Pestisida dengan 
harganya dalam satu periode musim tanam adalah 1,82 (NPM >1). Hal itu menunjukkan bahwa secara ekonomis alokasi dari faktor produksi pestisida pada tingkat penggunaan sebesar 6,77 liter belum efisien. Oleh sebab itu penggunaan input pestisida harus tambah hingga berada pada tingkat optimum.

Secara keseluruhan pengalokasian dari keenam faktor produksi tersebut ternyata tidak satupun yang mencapai optimum. Hal tersebut ditunjukkan dari nilai rata-rata efisiensi harga yang lebih dari satu yaitu sebesar 2,38 maka dapat disimpulkan bahwa usahatani Kelapa Dalam di kecamatan Gaung Anak Serka belum efisien. Hal ini senada dengan penelitian Pasaribu, dkk (2016) bahwa $87 \%$ atau 39 orang petani tidak efisien secara alokatif.

\section{EFISIENSI EKONOMI}

Efisiensi Ekonomi merupakan hasil kali antara seluruh efisiensi teknis dengan efisiensi harga dari seluruh faktor input (EE = ET $x$ EA). Apabila nilai EE $>1$ maka dikatakan belum efisien dan sebaliknya bila $\mathrm{EE}<1$ maka dapat dikatakan efisiensi ekonomis tidak efisien (Soekartawi, 2002).

Berdasarkan Tabel 4 nilai efisiensi ekonomis usahatani Kelapa Dalam di kecamatan Gaung Anak Serka sebesar 1,75. Maka dapat disimpulkan bahwa usahatani Kelapa Dalam di kecamatan Gaung Anak Serka belum efisien secara ekonomis, sehingga untuk mencapai efisiensi secara keseluruhan maka masih dimungkinkan adanya penambahan input-input produksi kecuali harga lahan yang pemakaiannya sudah melebihi batas optimum.

\section{KESIMPULAN DAN SARAN}

\section{KESIMPULAN}

Penelitian Analisis Efisiensi Penggunaan Faktor Produksi Pada Usahatani Kelapa Dalam Kecamatan Gaung Anak Serka dapat diambil kesimpulan sebagai Berikut:

1. Tingkat efisiensi teknis rata-rata yang dicapai 72,94 persen dari produktivitas maksimum. Hal ini menunjukkan bahwa usahatani Kelapa Dalam di Kecamatan Gaung Anak Serka sudah efisien, tetapi masih terdapat peluang sebesar 27,06 persen untuk mencapai produktivitas maksimum.

2. Perkebunan Kelapa Dalam didaerah penelitian belum efisien secara alokatif/harga. Rata-Rata nilai efisiensi alokatif secara keseluruhan adalah 2,40.

3. Perkebunan kelapa didaerah penelitian belum efisien secara ekonomis karena nilai efisiensi ekonomis yang didapatkan adalah 1,75.

\section{SARAN}

Dari kesimpulan diatas, dapat diajukan beberapa saran agar pengelolaan usahatani Kelapa Dalam lebih efisien sehingga mampu untuk berproduksi lebih optimal.

1. Perlu melakukan perluasan areal tanaman, meningkatkan jumlah penggunaan tenaga kerja, melakukan peremajaan kelapa terhadap tanaman yang sudah tua dan rusak. Diharapkan pemerintah memberikan bantuan berupa bibit unggul nasional. Diharapkan adanya subsidi terhadap saprodi (pupuk, herbisida dan pestisida) oleh pemerintah.

2. Pemerintah melalui dinas terkait perlu menyiapkan tenaga ahli/pendamping lapangan (penyuluh) yang bisa membimbing petani.

\section{DAFTAR PUSTAKA}

Abdurachman, A., Anny Mulyani, 2003, Pemanfaatan Lahan Berpotensi untuk Pengembangan Produksi Kelapa, Jurnal Litbang Pertanian, vol. 22, No. 1, 24-32.

Anyanwu, S.O., A. E. Kalio, S. O. Olatunji and L. Akonye, 2014, A Stochastic Frontier Production Function Approach to Technical Efficiency among Cassava Farmers in Rivers State, Nigeria, Asian Journal of Agricultural Extension, Economics \& Sociology. vol. 3, No. 6, 746755. 
Aumora, N.S. Djaimi Bakce., Novia Dewi, 2016, Analisis Efisiensi Produksi Usahatani Kelapa di Kecamatan Pulau Burung Kabupaten Indragiri Hilir. Jurnal Sorot, vol. 11, No. 1, 47-59.

Badan Pusat Statistik, 2015, Indragiri Hilir dalam Angka, Indragiri Hilir, Tembilahan

Coelli TJ, Rao DSP, O’Donnel CJ, Battese GE, 2005, An Introduction to Efficiency and Productivity Analysis.Second Edition. New York: Springer Science and Business Media, Inc

Damanik, S., 2007, Strategi Pengembangan Agribisnis Kelapa (Cocos Nucifera) Untuk Meningkatkan Pendapatan Petani di Kabupaten Indragiri Hilir, Riau. Perspektif. vol. 6, No. 2, 94-104.

Lamusa, A. 2005. Faktor-Faktor yang Mempengaruhi Kelapa Dalam di Desa Labuan Lele Kecamatan Tawaeli Kabupaten Donggala. J.Agroland, Vol 12, No 3, 254-260.

Margono, H., Subhash C. Sharma., 2004, Technical Efficiency and Productivity Analysis in Indonesian Provincial Economies. Southern Illinois University Carbondale Open SIUC. Discussion Papers. Paper 26.

McEachern, W. 2001. Pengantar Ekonomi Mikro. PT. Salemba Empat, Jakarta.

Miller, R. L., R. E. Meiners, 2000. Teori Ekonomi mikro Intermediate. Raja Grafindo Persada, Jakarta.

Nicholson, W. 2002. Mikroekonomi Intermediate dan Aplikasinya. Erlangga, Jakarta

Pangkey, M.C., Vecky, A.J. Masinambow., Albert T. Londa., 2016, Perbandingan Tingkat Pendapatan Petani Kelapa di Kabupaten Minahasa Selatan (Studi Kasus di Desa Ongkaw I dan Desa Tiniawangko Kecamatan Sinonsayang). Jurnal Berkala Ilmiah Efisiensi, vol.16, No. 02, 233-242.
Pasaribu, A., Djaimi Bakce., Novia Dewi., 2016, Analisis Efisiensi Produksi Usahatani Kelapa di Kecamatan Keritang Kabupaten Indragiri Hilir. JOM Faperta, vol.3, No.1, 1-11

Rekha, S., 2016, Technical Efficiency of Coconut Production in Karnataka: A Frontier Production Function Approach. Thesis. Department of Mathematics and Statistics College of Agriculture. Jabalpur, Madhya Pradesh.

Soekartawi. 1993. Resiko dan Ketidak Pastian dalam Agribisnis, PT. Raja Grafindo Persada, Jakarta.

Soekartawi. 1995. Analisis Usahatani, UI Press, Jakarta.

Soekartawi., 2002, Prinsip Dasar Ekonomi Pertanian; Teori dan Aplikasi. PT Raja Grapindo Persada, Cetakan Keempat. Jakarta.

Soekartawi. 2003. Teori Ekonomi Produksi dengan Pokok Bahasan Analisis Fungsi Produksi Coob Douglas. PT. Raja Grafindo Persada, Jakarta.

Soekartawi. 2005. Agribisnis Teori dan Aplikasinya, PT. Raja Grafindo Persada, Jakarta.

Tarigans, D.D., 2005, Diversifikasi Usahatani Kelapa sebagai Upaya untuk Meningkatkan Pendapatan Petani. Perspektif, vol.4, No.2, 71-78

Vaulina, S. dan Bahri, S., 2015, Produksi dan Pendapatan Petani Kelapa Dalam (Cocos Nucifera Linn) di Kabupaten Indragiri Hilir Propinsi Riau. Prosiding Seminar Nasional Kristalisasi Paradigma Agribisnis dalam Pembangunan Ekonomi dan Pendidikan Tinggi. IPB International Convention Center-Bogor. Hal. 183-198.

Vaulina, S., 2012, Kontribusi Perkebunan Kelapa DalamTerhadap Perekonomian Wilayah di Kabupaten Indragiri Hilir Propinsi Riau. Jurnal Agribisnis Terpadu. vol.5, No.2, 9-22. 
